\title{
SELECTION OF EUCALYPTUS CLONES AND ADJUSTMENT OF POTASSIUM DOSES FOR EXTENDED DROUGHT IN BAHIA SAVANNA ${ }^{1}$
}

Thalita Fernanda Sampaio ${ }^{2 *}$, Tiago Elias Dalcin ${ }^{3}$, Julio Cesar Bogiani ${ }^{4}$, Edson Seizo Mori ${ }^{5}$ and Iraê Amaral Guerrini $^{6}$

\footnotetext{
${ }^{1}$ Received on 09.02.2015 accepted for publication on 05.10.2016.

${ }^{2}$ Universidade Estadual Paulista Júlio de Mesquita Filho, Programa de Pós-Graduação em Ciência Florestal, Botucatu, SP - Brasil. E-mail: <thalitafs2003@yahoo.com.br>.

${ }^{3}$ Faculdade Arnaldo Horácio Ferreira, Graduando em Agronomia, Luís Eduardo Magalhães, BA-Brasil. E-mail: <a-dalcin@uol.com.br>. ${ }^{4}$ Empresa Brasileira de Pesquisa Agropecuária, Embrapa Algodão, Centro Nacional de Pesquisa de Algodão, Campina Grande, PB - Brasil. E-mail: < julio.bogiani@embrapa.br>.

${ }^{5}$ Universidade Estadual Paulista Júlio de Mesquita Filho, Departamento de Produção e Melhoramento Vegetal, Botucatu, SP - Brasil. E-mail: <esmori@fca.unesp.br>.

${ }^{6}$ Universidade Estadual Paulista Júlio de Mesquita Filho, Departamento de Solos e Recursos Ambientais, Botucatu, SP - Brasil. E-mail:<iguerrini@fca.unesp.br>.

*Corresponding author.
}

\begin{abstract}
The use of clones adapted to regions with water deficit caused by well-defined and prolonged dry periods, as happens in the western part Bahia, is a way to overcome water stress. The adjustment of potassium $(\mathrm{K})$ also influences this aspect, because it regulates the opening and closing of stomata, impeding water loss by plants and making them more efficient in water use. Therefore, the aim of this study was to evaluate the performance of eucalyptus clones grown for energy production in response to potassium levels in soil and climate conditions, in the municipality of Luis Eduardo Magalhães, located in western Bahia state. A randomized block with four replications in a split plot was used as experimental design. Six eucalyptus clones (AEC-056, CEA-144, CEA-220, CEA-224, CEA-103 and CEA-1528) and four doses of K2O (0, 30, 60 and 120 $\mathrm{kg} \mathrm{ha}^{-1}$ ) were tested. At two years old, clone 1528 showed greatest productivity, with the tallest height and trunk diameter, while 056 showed the lowest performance. Different K requirements were observed among eucalyptus clones for both growth and productivity.
\end{abstract}

Keywords: Water deficit; Eucalyptus growth; Potassium fertilization.

\section{SELEÇÃO DE CLONES DE EUCALIPTO, EM IDADE PRECOCE, E AJUSTE DE DOSES DE POTÁSSIO PARA PERÍODOS PROLONGADOS DE SECA NO CERRADO DA BAHIA}

\begin{abstract}
RESUMO - O uso de clones adaptáveis a regiões com déficit hídrico e épocas bem definidas e prolongadas de seca, como acontece no Oeste da Bahia, é uma forma de superar tal estresse. O manejo do K também interfere neste aspecto, pois regula a abertura e fechamento dos estômatos, impedindo que a planta perca água desnecessariamente, tornando-a mais eficiente no uso da água. Logo, o objetivo deste trabalho foi avaliar o desempenho produtivo de clones de eucalipto e doses de potássio para as condições edafoclimáticas do município de Luis Eduardo Magalhães, localizado no Oeste do estado da Bahia, visando à produção energética. O delineamento experimental foi em blocos ao acaso com quatro repetições, no esquema de parcelas subdivididas. Foram testados seis clones de eucalipto (AEC-056, AEC-144, AEC-220, AEC-224, AEC-103 e AEC-1528), e quatro doses de K2O (0, 30, 60 e $120 \mathrm{~kg} \mathrm{ha-1).} \mathrm{Aos} \mathrm{dois} \mathrm{anos} \mathrm{de} \mathrm{idade} \mathrm{o} \mathrm{clone} \mathrm{AEC} 1528$ foi o que apresentou maior crescimento em altura e diâmetro enquanto o AEC 056 o menor. O clone AEC 1528 apresentou maior produtividade. Notouse exigência diferenciada de Kentre os clones de eucalipto tanto para o crescimento quanto produtividade.
\end{abstract}

Palavras-Chave: Déficit hídrico; Crescimento de eucalipto; Adubação potássica. 


\section{INTRODUCTION}

The use of biomass produced by planted eucalyptus forests has been recognized for its potential to generate renewable energy, reducing the need for fossil fuels (PROTÁSIO et al., 2013). However, areas allocated to planting eucalyptus trees are normally marginal, by having nutrient-poor soils and unfavorable hydrological conditions, since areas with higher potential productivity are typically used to grow annual crops with fast economic return, such as soybeans, corn and cotton.

Water is a primary resource for productivity of any crop. It determines the structure, growth, nutrient uptake and transport and metabolism of plants (MENESES et al., 2006). According to Larcher (2006), the first responses to water deficiency are reduced turgescence, through closing of stomata, and reductions of photosynthesis and cell length.

Potassium $(\mathrm{K})$ is the nutrient that regulates the opening and closing of the stomata, in turn controlling water loss through evapotranspiration. Thus, stomatal closure prevents unnecessary water loss and maintains the osmotic potential of cells (JONES; WILKINS, 1971; LIMA et al., 2003). This nutrient also increases plant resistance to diseases and the transport capacity of the phloem, maintaining more water in the tissues during drought periods (MALAVOLTA et al., 1997; MALAVOLTA, 2006).

Many plants can become acclimated to shortage of water by osmotic adjustment, enabling maintenance of cell turgescence and consequently growth, with low water potentials in the leaves (NOGUEIRA et al., 2001; ARRIEL, 2004).

Research in the area of genetic improvement with eucalyptus clones and hybrids has led to the development of varieties that are more resistant to water deficit, with biomass yield of 40 to $60 \mathrm{~m}^{3} \mathrm{ha}^{-1} \mathrm{year}^{-1}$. In Brazil it is even possible to find areas producing as much as $70 \mathrm{~m}^{3} \mathrm{ha}^{-1}$ year $^{-1}$ (CIB, 2008), as well as plants with age of 6 years reaching average height of around 35 meters and productivity greater than $50 \mathrm{~m}^{3} \mathrm{ha}^{-1}$ year $^{-1}$ (Baesso, 2010). Additionally, good adjustment of the potassium fertilization also helps the plant to overcome water stress.

The western part of the state of Bahia stands out in Brazil for good potential to produce eucalyptus, but the rainfall regime is very specific, with well-defined rainy and dry periods during the year, where the dry season on average lasts about five months (DOURADO et al., 2013). The municipality of Luis Eduardo Magalhães in western Bahia has climate and soil conditions similar to those elsewhere in Brazil where planted eucalyptus forests are extensive and highly productive. This study presupposes the existence of commercially available clones with sufficient adaptation potential to develop and grow adequately in this region.

Therefore, the aim of this study was to evaluate the initial growth of six eucalyptus clones supplied with four $\mathrm{K}$ rates, to assess the suitability for planting in the edaphoclimatic conditions of western Bahia.

\section{MATERIALAND METHODS}

The experiment was conducted on the Palmeiras I farm, located in the municipality of Luis Eduardo Magalhães in western Bahia (geographic coordinates $12^{\circ} 202333$ South latitude and $45^{\circ} 562273$ West longitude), at an average altitude of 810 meters. The experiment was established between November 15 and 20, 2011.

The terrain in the area is flat and the soil is classified as red-yellow latosol, with sandy texture (EMBRAPA, 2006). The result of the chemical soil analysis in the topmost layer $(0-20 \mathrm{~cm})$ before the start of the experiment showed: $\mathrm{pH}\left(\mathrm{CaCl}_{2}\right)$ of 4,$5 ; 14 \mathrm{~g} \mathrm{dm}^{-3}$ of organic matter; $4 \mathrm{mg} \mathrm{dm}^{-3}$ of $\mathrm{P}$ (resin); $27.0-0.6-13.0$ and $4.0 \mathrm{mmol}_{\mathrm{c}}$ $\mathrm{dm}^{-3}$ of $(\mathrm{H}+\mathrm{Al})-\mathrm{K}^{+}-\mathrm{Ca}^{2+}$ and $\mathrm{Mg}^{2+}$, respectively; $0.2-0.2-64.0-0.6$ and $1.2 \mathrm{mg} \mathrm{dm}^{-3}$ of $\mathrm{B}-\mathrm{Cu}-\mathrm{Fe}$ - Mn and $\mathrm{Zn}$, respectively, and base saturation of $40 \%$. The analysis of the physical soil characteristics showed 866,97 and $37 \mathrm{~g} \mathrm{~kg}^{-1}$ of total sand, clay and silt, respectively.

The temperature during the experimental period varied from 10 to $39^{\circ} \mathrm{C}$. The data on rainfall and relative humidity in this period are shown in Figure 1. The average annual precipitation in the base period from 1997 to 2010 was $1,438 \mathrm{~mm}$.

The experiment was conducted in random blocks with 4 repetitions, in a design with subdivided plots, with $4 \mathrm{~K}$ doses (plots) and 6 eucalyptus clones (subplots), in a total of 16 plots and 96 sub-plots. Each sub-plot consisted of 36 plants ( 6 rows with 6 plants each), with spacing of $3.0 \mathrm{~m}$ between rows and $2.0 \mathrm{~m}$ between plants, covering an area of $216 \mathrm{~m}^{2}$ each, for a total area of $2.07 \mathrm{ha}$. The useful area of each plot 


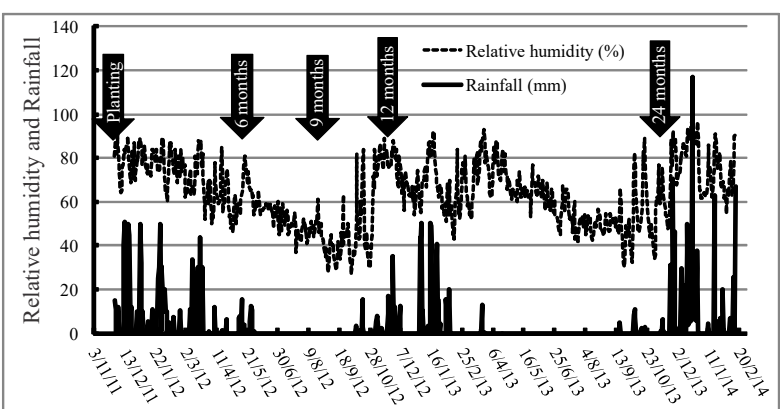

Figure 1 - Rainfall ( $\mathrm{mm}$ ) and relative humidity observed during the study (December 2011 to February 2014).

Figura 1 - Precipitação pluviométrica e umidade relativa ocorridas na região de estudo durante o período de Dez/2011 a Fev/2014.

was composed of the 16 central plants, with 20 plants on the borders.

The eucalyptus clones used were developed as part of the genetic improvement program of the steel company ArcelorMittal, adapted for climate conditions similar to those in Luis Eduardo Magalhães, called: AEC056, AEC-144, AEC-220, AEC-224, AEC-103 and AEC1528. Clone 1528 is a hybrid from controlled pollination of $E$. grandis x E. urophylla, while the others are spontaneous hybrids of E. urophylla, obtained from different matrixes. The height and stem diameter of the seedlings of each clone were measured before planting.

The $\mathrm{K}$ doses were provided by potassium chloride, with quantities of $0,30,60$ and $120 \mathrm{~kg} \mathrm{ha}^{-1} \mathrm{~K}_{2} \mathrm{O}$. The rate recommended by Gonçalves et al. (1996) is $60 \mathrm{~kg}$ $\mathrm{ha}^{-1} \mathrm{~K}_{2} \mathrm{O}$. The quantities of the other nutrients supplied by fertilization were also calculated as recommended by Gonçalves et al. (1996) and were: $60 \mathrm{~kg} \mathrm{ha}^{-1} \mathrm{~N}$ and $\mathrm{P}_{2} \mathrm{O}_{5}, 1.25 \mathrm{~kg} \mathrm{ha}^{-1} \mathrm{Mn} ; 1 \mathrm{~kg} \mathrm{ha}^{-1} \mathrm{~B}$ along with $0.350 \mathrm{t}$ $\mathrm{ha}^{-1}$ of dolomitic limestone. The fertilizer sources were ammonium sulfate (AS), simple superphosphate (SS), manganese sulfate (MS) and boric acid (BA).

The lime was applied by spreading in the entire experimental area. The fertilizers were applied according to the following scheme: for $\mathrm{N}$ and $\mathrm{K}, 1 / 3$ of the recommended dose was applied at the moment of planting, $1 / 3$ three months after planting and $1 / 3$ one year after planting; for $\mathrm{P}, 180 \mathrm{~kg} \mathrm{ha}^{-1} \mathrm{SS}$ was spread in the total area before planting, followed by corrective fertilization and $60 \mathrm{~kg} \mathrm{ha}^{-1} \mathrm{P}_{2} \mathrm{O}_{5}\left(334 \mathrm{Kg} \mathrm{SS} \mathrm{ha}^{-1}\right)$ in furrows alongside the rows; Mn and B were diluted in 200 liters of water and sprayed in the soil with a tractor just after planting.
Glyphosate was applied to kill weeds along with manual weeding after the start of the experiment until the shade from the trees reduced the establishment and competition of invasive species. Leaf-cutter ants were controlled with formicide baits (based on sulfonamide) just before and after planting.

The height and trunk diameter were measured at $6,9,12$ and 24 months after planting, and the volumetric production was determined 24 months after planting (end of the experiment).

The means of the measured data were compared by the Tukey test at 5\% confidence, when the F-value from the analysis of variance was significant. The results of the potassium doses were analyzed by regression to choose the model with best fit, when significant at $5 \%$ probability.

\section{RESULTS}

The $\mathrm{K}_{2} \mathrm{O}$ dose in most cases affected the height of the clones, with distinct behavior for each clone (Figure 2). Six months after the start of the experiment (Figure 2A), clones 056 and 103 presented increased growth starting with rates of 41.5 and $50 \mathrm{~kg} \mathrm{ha}^{-1}$, respectively. For clone 144, the maximum dose tested was the only one that promoted height increment (129.3 $\mathrm{cm}$ ), while for clone 220 the threshold dose was 100.5 $\mathrm{kg} \mathrm{ha}^{-1}$. Clone 224 did not respond to increased $\mathrm{K}_{2} \mathrm{O}$ while clone 1528 showed a linear trend.

At 9 months of age (Figure 2B), clone 220 presented greatest height at the dose of $88.5 \mathrm{~kg} \mathrm{ha}^{-1} \mathrm{~K}_{2} \mathrm{O}$. Clone 1528 continued showing linear growth with rising rates and clone 056 also presented the same behavior at 6 months, with increased growth observed starting at a dose of $40 \mathrm{~kg} \mathrm{ha}^{-1}$. Clones 103, 144 and $224 \mathrm{did}$ not respond to the different doses at 9 months of age.

At age of 12 months (Figure 2C), clone 224 presented the greatest height at a dose of $72.1 \mathrm{~kg} \mathrm{ha}^{-}$ ${ }^{1} \mathrm{~K}_{2} \mathrm{O}$. At this age, clones 056,103 and 220, together with clone 1528 , showed linear response with increase of the $\mathrm{K}_{2} \mathrm{O}$ rates tested. Clone 144 was not affected by the doses.

At 24 months of age (Figure 2D), all the clones presented quadratic behavior, indicating the quantity of $\mathrm{K}_{2} \mathrm{O}$ necessary for maximum height of each clone. The $\mathrm{K}_{2} \mathrm{O}$ rates that provided greatest growth for clones $056,103,144,220,224$ and 1528 were $80,52,61,65$, 120 and $73 \mathrm{~kg} \mathrm{ha}^{-1}$, respectively.

Revista Árvore, Viçosa-MG, v.40, n.6, p.1031-1039, 2016

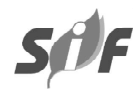



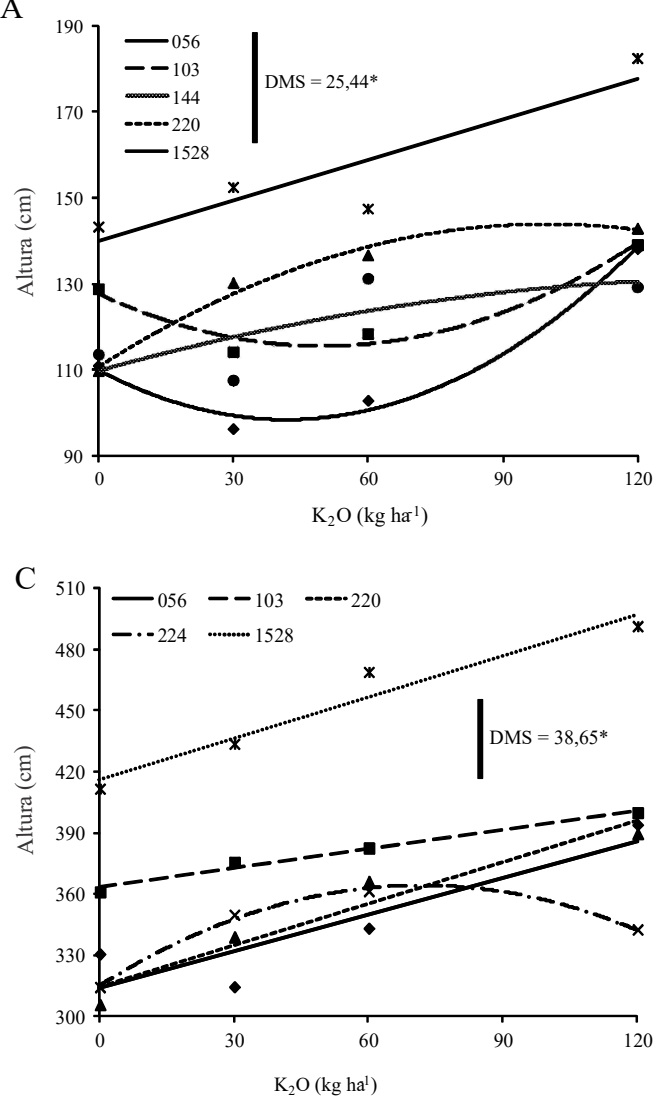

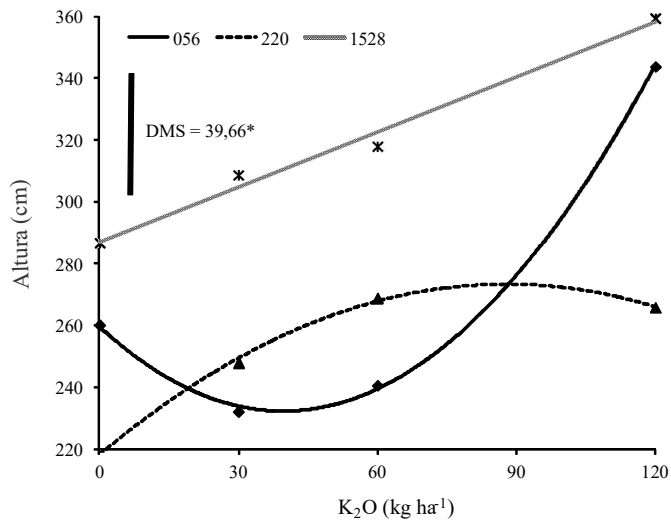

$\mathrm{D}$

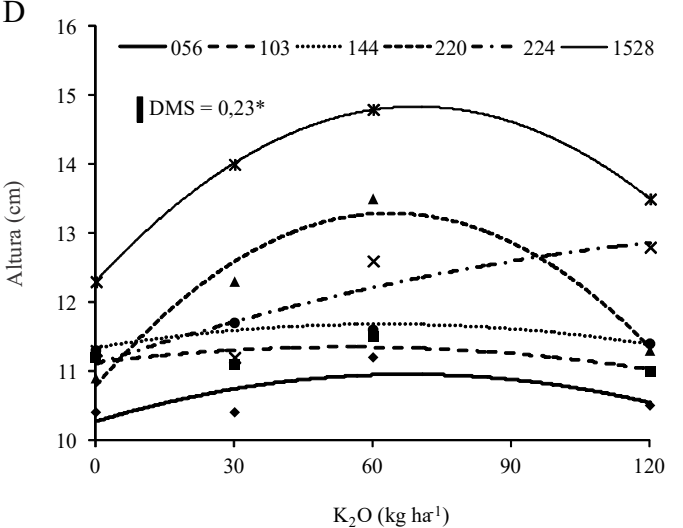

Figure 2-Height at 6 (A), 9 (B), 12 (C) and 24 (D) months of age. ** Significant at 1\% probability level. * Significant at $5 \%$ probability level. $L S D=$ least significant difference.

Figura 2 - Crescimento em altura aos $6(A), 9(B), 12$ (C) e 24 (D) meses de idade. **Significativo a 1\% de probabilidade. * Significativo a 5\% de probabilidade. DMS = diferença mínima significativa.

The regression equations to estimate the height of the eucalyptus clones under different $\mathrm{K}_{2} \mathrm{O}$ rates at 3, 6, 9, 12 and 24 months after planting are reported in Table 1.

With regard to trunk diameter (Figure 3), in general the response of the clones in function of the $\mathrm{K}_{2} \mathrm{O}$ doses was similar to that for height (Figure 2). The regression equations to estimate the diameter of the plants under different $\mathrm{K}_{2} \mathrm{O}$ doses at $6,9,12$ and 24 months after planting are shown in Table 1 .

At 6 months of age (Figure 3A), clone 056 presented increased diameter starting at the dose of $36.8 \mathrm{~kg} \mathrm{ha}^{-1}$. Clones 103 and 1528 presented linear increase in diameter in function of rising $\mathrm{K}_{2} \mathrm{O}$ doses. Clones 144 and 220 showed greatest increment in diameter at respective doses of 82.8 and $81.7 \mathrm{~kg} \mathrm{ha}^{-1} \mathrm{~K}_{2} \mathrm{O}$. There was no dose effect for clone 224 .

At 9 months of age, clone 056 presented increase in diameter starting at $28 \mathrm{~kg} \mathrm{ha}^{-1} \mathrm{~K}_{2} \mathrm{O}$. Clones 144,224 and 220 had the largest trunk diameters at doses of $66,61.5$ and $135.5 \mathrm{~kg} \mathrm{ha}^{-1} \mathrm{~K}_{2} \mathrm{O} \mathrm{ha}^{-1}$, respectively. Clone 1528 presented linear increase of diameter with rising doses. There was no effect of the doses on clone 103 (Figure 3B).

At age of 12 months, clone 056 presented increased diameter starting at the $\mathrm{K}_{2} \mathrm{O}$ dose of $13.5 \mathrm{~kg} \mathrm{ha}^{-1}$. Clones 144 and 224 showed largest diameters at respective rates of 26 and $19 \mathrm{~kg} \mathrm{ha}^{-1} \mathrm{~K}_{2} \mathrm{O}$. Clone 1528 continued 
Table 1 - Equations to estimate the height of plants, the diameter $(\mathrm{mm})$ and the volume $(\mathrm{V}) \mathrm{in}^{3} /$ tree of six Eucalyptus clones submitted to doses of $\mathrm{K}_{2} \mathrm{O}$ in Luis Eduardo Magalhães, BA state.

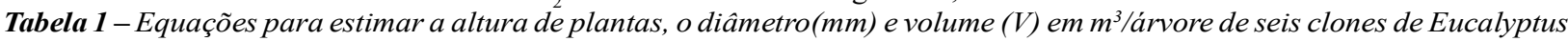
submetidas à doses de $\mathrm{K}_{2} \mathrm{O}$, em Luis Eduardo Magalhães, BA.

\begin{tabular}{|c|c|c|c|c|}
\hline \multirow[t]{2}{*}{ Clones } & Equations & \multicolumn{2}{|r|}{ Equations } & \multirow[t]{2}{*}{$\mathrm{R}^{2}$} \\
\hline & Height of plants at 6 months & \multicolumn{2}{|r|}{ Height of plants at 9 months } & \\
\hline 056 & $Y=0.0066 x^{2}-0.5473 x+109.86$ & $0.98 * *$ & $Y=0.0173 x^{2}-1.3743 x+259.56$ & $0.99 * *$ \\
\hline 103 & $Y=0.0049 x^{2}-0.4852 x+127.69$ & $0.95 *$ & Not significant $-—$ & \\
\hline 144 & $y=-0.001 x^{2}+0.2884 x+109.91$ & $0.57 *$ & Not significant - & \\
\hline 220 & $y=-0.0033 x^{2}+0.6641 x+110.77$ & $0.98 * *$ & $y=-0.0071 x^{2}+1.2534 x+218.26$ & $0.99 * *$ \\
\hline 224 & Not significant & - - & Not significant - - & \\
\hline \multirow[t]{2}{*}{1528} & $y=0.3137 x+139.98$ & $0.82 * *$ & $y=0.589 x+287.38$ & $0.98 * *$ \\
\hline & Height of plants at 12 months & \multicolumn{3}{|c|}{ Height of plants at 24 months } \\
\hline 056 & $y=0.6014 x+313.9$ & $0.80 * *$ & $y=-0.0001 x^{2}+0.0201 x+10.272$ & $0.55 * *$ \\
\hline 103 & $y=0.3123 x+363.28$ & $0.98 * *$ & $y=-8 E-05 x^{2}+0.0083 x+11.124$ & $0.49 * *$ \\
\hline 144 & Not significant & - - & $y=-9 E-05 x^{2}+0.011 x+11.341$ & $0.80 * *$ \\
\hline 220 & $\mathrm{y}=0.6819 \mathrm{x}+314.2$ & $0.93 * *$ & $y=-0.0006 x^{2}+0.0785 x+10.791$ & $0.96 * *$ \\
\hline 224 & $y=-0.0095 x^{2}+1.3702 x+315.01$ & $0.99 * *$ & $y=-6 E-05 x^{2}+0.0222 x+11.106$ & $0.79 * *$ \\
\hline \multirow[t]{2}{*}{1528} & $\mathrm{y}=0.6748 \mathrm{x}+415.9$ & $0.94 * *$ & $\mathrm{y}=-0.0005 \mathrm{x}^{2}+0.0731 \mathrm{x}+12.295$ & $0.99 * *$ \\
\hline & Diameter at 6 months & \multicolumn{3}{|c|}{ Diameter at 9 months } \\
\hline 056 & $y=0.0006 x^{2}-0.0441 x+14.765$ & $0.89 * *$ & $y=0.0012 x^{2}-0.0665 x+27.353$ & $0.99 * *$ \\
\hline 103 & $\mathrm{y}=0.02 \mathrm{x}+15.9$ & $0.75 * *$ & Not significant & - \\
\hline 144 & $y=-0.0004 x^{2}+0.0662 x+16.77$ & $0.42 * *$ & $y=-0.0008 x^{2}+0.1056 x+31.206$ & $0.48 *$ \\
\hline 220 & $y=-0.0007 x^{2}+0.1144 x+15.855$ & $0.97 * *$ & $y=-0.0006 x^{2}+0.1627 x+25.655$ & $0.99 * *$ \\
\hline 224 & Not significant & - & $y=-0.0008 x^{2}+0.0986 x+29.486$ & $0.86^{*}$ \\
\hline \multirow[t]{2}{*}{1528} & $y=0.0473 x+21.44$ & $0.95 * *$ & $\mathrm{y}=0.0607 \mathrm{x}+36.54$ & $0.98 * *$ \\
\hline & Diameter at 12 months & \multicolumn{3}{|c|}{ Diameter at 24 months } \\
\hline 056 & $y=0.0162 x^{2}-0.4383 x+40.125$ & $0.99 * *$ & $Y=-0.0012 x^{2}+0.2002 x+84.367$ & $0.96 * *$ \\
\hline 103 & Not significant & - & $y=0.0979 x+88.36$ & $0.79 * *$ \\
\hline 144 & $y=-0.0075 x^{2}+0.389 x+43.38$ & $0.28 *$ & Not significant & - \\
\hline 220 & $\mathrm{y}=0.2351 \mathrm{x}+38.86$ & $0.87 * *$ & $\mathrm{y}=0.0401 \mathrm{x}+94.22$ & $0.30 *$ \\
\hline 224 & $y=-0.03 x^{2}+1.1246 x+41.747$ & $0.98 * *$ & $y=-0.0015 x^{2}+0.1999 x+95.447$ & $0.65 * *$ \\
\hline 1528 & $\mathrm{y}=0.1243 \mathrm{x}+56.10$ & $0.53 * *$ & $y=0.057 x+93.96$ & $0.48 * *$ \\
\hline Clones & \multicolumn{3}{|c|}{ Volume (V) in $\mathrm{m}^{3} /$ tree } & $\mathrm{R}^{2}$ \\
\hline 056 & \multirow{2}{*}{\multicolumn{3}{|c|}{$\begin{array}{l}y=-2.5 \mathrm{E}-06 \mathrm{x}^{2}+0.0004 \mathrm{x}+0.0432 \\
\text { Not significant }\end{array}$}} & $0.99 * *$ \\
\hline 103 & \multicolumn{2}{|c|}{ Not significant } & & - \\
\hline 144 & \multicolumn{3}{|c|}{$\mathrm{y}=2 \mathrm{E}-05 \mathrm{x}+0.07$} & $0.20 *$ \\
\hline 220 & \multicolumn{3}{|c|}{$y=-4 E-06 x^{2}+0.0005 x+0.0558$} & $0.86 * *$ \\
\hline 224 & \multicolumn{3}{|c|}{$y=-4 E-06 x^{2}+0.0006 x+0.0582$} & $0.91 * *$ \\
\hline 1528 & \multicolumn{3}{|c|}{$y=-5 E-06 x^{2}+0.0007 x+0.063$} & $0.92 * *$ \\
\hline
\end{tabular}

presenting a linear increase in diameter, like the pattern observed at 6 and 9 months. At this age, clone 220 also presented linear diameter increase in function of rising doses applied, but there was no effect of the doses on clone 103 (Figure 3C).

Finally, at 24 months of age (Figure 3D), clones 1528, 103 and 220 showed linear diameter increase with rising doses of $\mathrm{K}_{2} \mathrm{O} \mathrm{ha}^{-1}$. Clones 056 and 224 presented quadratic behavior, whereby clone 056 had the largest diameter when applying $83.5 \mathrm{~kg} \mathrm{ha}^{-1}$ and clone 224 when using $66.6 \mathrm{~kg} \mathrm{ha}^{-1}$. At this age, clone 144 was not affected by the different doses tested.
In the analysis of volumetric production at 24 months, the average $\mathrm{K}_{2} \mathrm{O}$ rate that promoted the largest wood volumes for the clones was around $70 \mathrm{~kg} \mathrm{ha}^{-1}$. Individually speaking (Figure 4), the doses that produced the largest wood volumes were $75,62.5,75$ and $70 \mathrm{~kg} \mathrm{ha}^{-1}$ for clones 056, 220, 224 and 1528, respectively. Clone 144 presented linear increment in wood volume in function of rising $\mathrm{K}_{2} \mathrm{O}$ doses, and there was no effect of the doses on clone 103 .

The regression equations chosen to estimate the wood volume of the eucalyptus clones under different $\mathrm{K}_{2} \mathrm{O}$ doses and age of 24 months are shown in Table 1.

Revista Árvore, Viçosa-MG, v.40, n.6, p.1031-1039, 2016 
A

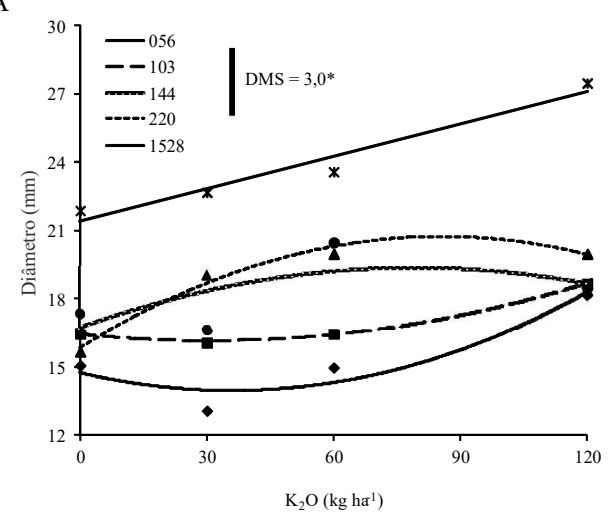

$\mathrm{C}$

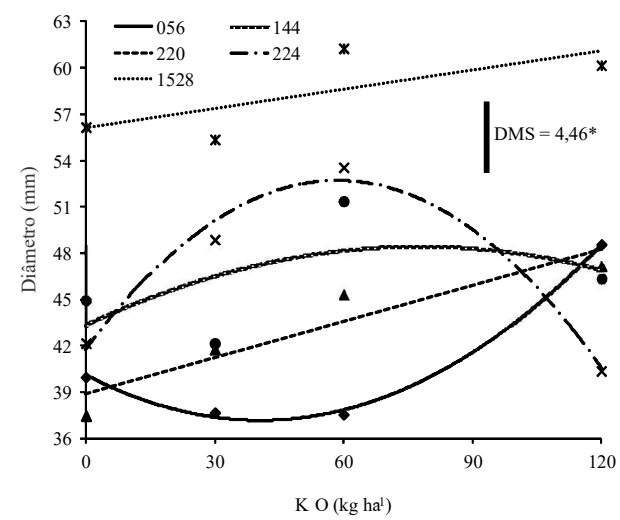

B

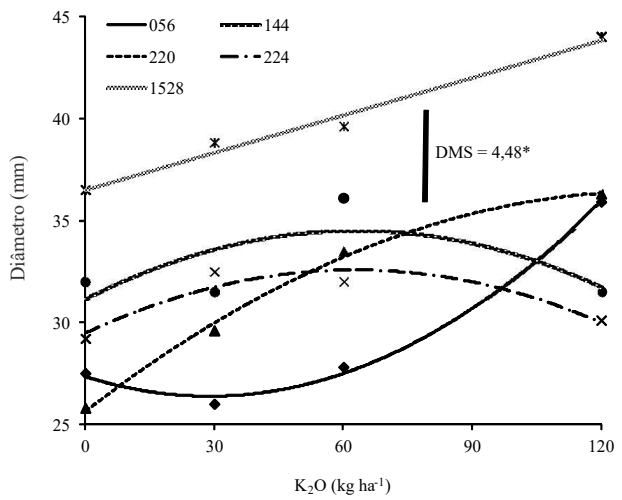

$\mathrm{D}$

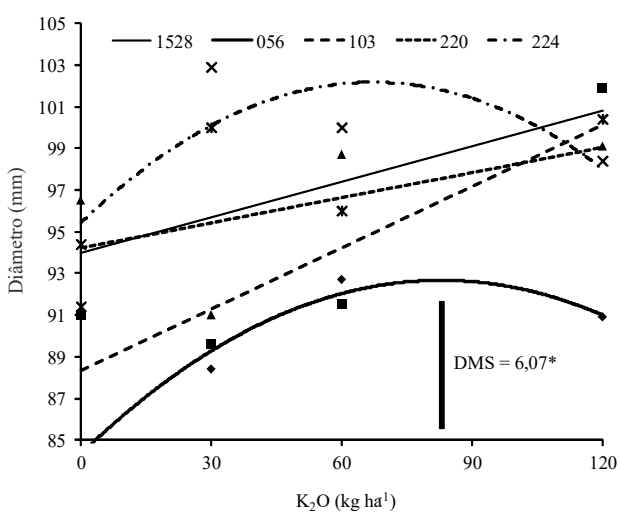

Figure 3 - Average trunk diameter at 6 (A), 9 (B), 12 (C) and 24 (D) months of age** Significant at $1 \%$ probability. * Significant at $5 \%$ probability. LSD = least significant difference.

Figura 3 - Médias do crescimento em diâmetro $6(A), 9(B), 12$ (C) e 24 (D) meses após o plantio. **Significativo a $1 \%$ de probabilidade. * Significativo a $5 \%$ de probabilidade. DMS = diferença mínima significativa.

\section{DISCUSSION}

The measurements made at 6 months of age corresponded to a period of heavy rains, and at this age all the clones except 224 presented statistically significant height increase, with 144 having the lowest height and 1528 the greatest. At 9 months, the height evaluations were conducted during the dry season and the results showed water stress, with some clones being more affected than others, causing high variability regarding growth. Only clones 056, 220 and 1528 presented significant growth in function of the doses of $\mathrm{K}_{2} \mathrm{O}$ tested.

Fernandes et al. (2013) assessed the behavior of four clones (VM01, VCC 0865, AEC 144 and AEC 224) under irrigated and non-irrigated regimes in a greenhouse and found that at 8 months of age, water deficiency affected the height and trunk diameter of all the clones, while in the irrigated treatment, clone 144 presented the greatest height and clone 224 the lowest.

Tatagiba et al. (2009) studied six clones of Eucalyptus spp. In response to water availability, and also observed that water deficiency stunted the height and diameter of the plants studied. According to Gonçalves and Passos (2000), water deficiency can directly affect the height and diameter because it reduces cell expansion and cell wall formation, and indirectly affects growth by influencing the availability of carbohydrates and production of growth regulators.

The measurements 12 months after planting corresponded to the maximum drought to which the 


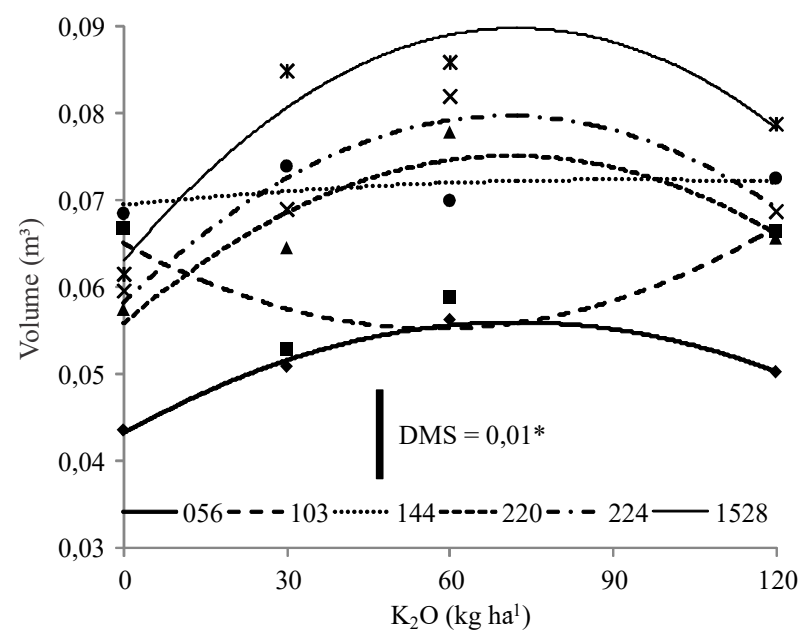

Figure 4 - Average volume $\left(\mathrm{m}^{3}\right)$ of each clone studied at 24 months old. * Significant at $5 \%$ probability level. LSD $=$ least significant difference.

Figura 4-Médias do volume, em m3, de cada clone estudado aos 24 meses após o plantio. * Significativo a 5\% deprobabilidade. $D M S=$ diferençaminimasignificativa .

plants were subjected. Despite the stress suffered, only clone 144 did not present a significant response to the $\mathrm{K}$ doses. Clones 056, 103, 220 and 1528 showed linear increase in growth in function of rising $\mathrm{K}_{2} \mathrm{O}$ doses, while clone 224 presented maximum height at that age with application of $60 \mathrm{~kg} \mathrm{ha}^{-1} \mathrm{~K}_{2} \mathrm{O}$. The measurements at 24 months of age corresponded to the start of the rainy season in the second year of the experiment (Figure 1). The results showed total stability of the growth data, indicating good acclimation of the clones, even those that grew less. The western region of Bahia is noted for prolonged water deficit with high variability, and in the two years of the experiment, the dry season was longer than normal, lasting about seven months (Figure 1).

The first six months after planting corresponded to the rainy season, and the average heights attained by clones $056,103,144,220,224$ and 1528 were 82 , $95,76,90,78$ and $123 \mathrm{~cm}$, while for diameter the numbers were 11.9, 13.8, 14.2, 15.4, 14.3 and $20.6 \mathrm{~mm}$, respectively. Note that in relative numbers, clone 1528 grew the most in the rainy period.

The measurements at 9 and 12 months allowed evaluating the increase during the critical period of water stress. The average increases in height during these three months for clones 056, 103, 144, 220, 224 and 1528 were $237,255,255,220,232$ and $294 \mathrm{~cm}$, respectively, and the diameter increments were 26,28 ,
$28,24,28$ and $35 \mathrm{~mm}$, respectively. Once again, in relative numbers clone 1528 grew more than the others. That finding reveals a possible advantage for development of this clone, because in the dry period it continued growing substantially. The growth behavior of clone 1528 indicates greater wood production than the others for climate conditions similar to those in the municipality of Luís Eduardo Magalhães, BA.

$\mathrm{K}$ is a very important nutrient for the osmotic balance in cells, since the cell turgor pressure, production of ATP and photosynthesis rate depend on this cation (MALAVOLTA, 2006). According to that author, under drought conditions, these processes either stop occurring or are greatly reduced, impairing plant growth, both in height and diameter. However, in the case of the clones tested here, both height and diameter continued to increase.

Considering that the objective of this study was to detect the clone best adapted to drought and hence the one that can grow the most during water stress periods, clone 1528 was best able to gain both height and diameter during the first two years. However, future measurements are necessary to confirm this pattern over the entire cycle of planted eucalyptus forests (seven years in Brazil).

With respect to wood volume, the average $\mathrm{K}_{2} \mathrm{O}$ rate that promoted the maximum productivity was 10 $\mathrm{kg} \mathrm{ha}^{-1}$ higher than the value found by Valeri et al. (1991), who in investigating the effect of doses of $\mathrm{N}, \mathrm{P}$ and $\mathrm{K}$ on production of $E$. grandis planted in quartzous sand, found the maximum production was obtained by applying an estimated dose of $61 \mathrm{~kg} \mathrm{ha}^{-1}$ $\mathrm{K}_{2} \mathrm{O}$.

Despite the overall linear trend for increase in wood volume with rising doses of $\mathrm{K}_{2} \mathrm{O}$ until the maximum dose tested, clone 144 showed virtually no increase in wood productivity with rising doses, making it in practice not economically suitable.

Galo (1993) found that the dose to attain $90 \%$ of maximum wood production for E. grandis at age of 6.5 years in Cerrado soils in the state of Minas Gerais was $108 \mathrm{~kg} \mathrm{ha}^{-1} \mathrm{~K}_{2} \mathrm{O}$, where the original $\mathrm{K}$ content in the soil was $0.59 \mathrm{mmol}_{\mathrm{c}} \mathrm{dm}^{-3}$.

Schimidt (1995) reported that to obtain $90 \%$ of maximum wood production, it was necessary to supply 60.7 and $50.7 \mathrm{mg} \mathrm{kg}^{-1} \mathrm{~K}$ to E. camaldulensis and $E$.

Revista Árvore, Viçosa-MG, v.40, n.6, p.1031-1039, 2016 
grandis, respectively, in studying the growth and uptake of $\mathrm{K}, \mathrm{Ca}$ and $\mathrm{Mg}$ by seedlings of these species in response to application of $\mathrm{K}$ in the soil $(0,30,90$, 180 and $270 \mathrm{mg} \mathrm{kg}^{-1}$ ) and the addition of correctives with different $\mathrm{Ca}: \mathrm{Mg}$ ratios.

Stape et al. (2004) studied Eucalyptus grandis x E. urophylla hybrids and observed that irrigation increased the trunk biomass productivity by $52 \%$. Gentil (2010) found a 62\% biomass increment in irrigated plots containing eucalypts in comparison with nonirrigated plots.

The results of this study show the behavior of the clones up to 2 years of age, during which the plants did not reach their maximum growth or leaf area. Each clone studied has distinct leaf traits of thickness and shape (width and length), so the evaporation rates and consequent water efficiency to overcome dry periods are also different.

It is natural to expect that as plants grow, their water demand will increase, and that in periods of water stress, the behavior of clones can change with age. This is confirmed by Battie Laclau (2013), who assessed the effects of potassium fertilization ( 0 and $335 \mathrm{~kg} \mathrm{ha}^{-1} \mathrm{KCl}$ broadcast) on the productive and physiological aspects of Eucalyptus grandis submitted to partial rain exclusion during 36 months and found that the addition of $\mathrm{K}$ improved the water relations in the leaves, control of stomatic movements and leaf gas exchanges, but worsened the water status during periods of intense drought, due to the greater growth and thus higher water demand.

In this respect, longer studies in these conditions are necessary to find varieties that are better adapted to extended droughts.

\section{CONCLUSIONS}

All the clones evaluated (056, 144, 220, 224, 103 and 1528) proved to be adaptable to the region of Luis Eduardo Magalhães in western Bahia, up to 24 months of age, since no plants of any of the clones died during the experimental period.

Clone 1528 was best adapted to the region's conditions, in terms of growth in height and trunk diameter and wood productivity, after all the intervals studied.

The potassium fertilization influenced the growth and productivity of the clones, with the average $\mathrm{K}_{2} \mathrm{O}$ dose of $70 \mathrm{~kg} \mathrm{ha}^{-1}$ providing the best results up to 24 months of age.

Evaluations at older ages are necessary to check the stability of the behavior of the clones over time.

\section{REFERENCES}

ARRIEL, E.F.; PAULA, R.C.; BAKKE, O.A.; ARRIEL, N.H.C. Divergência genética em Cnidoscolus phyllacanthus (MART.) Pax et K. Hoffm. Revista Brasileira de Oleaginosas e Fibrosas, v.8, n.2/3, p.813822, 2004.

BAESSO, R.C.E.; RIBEIRO, A.; SILVA, M.P. Impacto das mudanças climáticas na produtividade do eucalipto na região norte do Espírito Santo e sul da Bahia. Ciência Florestal, v.20, n.2, p.335-344, 2010.

BATTIE LACLAU, P.R.F. Efeitos da adubação potássica sobre a adaptação à seca do Eucalyptus grandis. 2013.137f. Tese (Doutorado Energia Nuclear na Agricultura e no Ambiente) - Centro de Energia Nuclear na Agricultura da Universidade de São Paulo. Piracicaba, 2013.

\section{CONSELHO DE INFORMAÇÕES SOBRE}

BIOTECNOLOGIA - CIB. Guia do Eucalipto. Oportunidades para um Desenvolvimento Sustentável, 2008. 20p. [accessed on Feb 18, 2014]. Available at http://cib.org.br/wp-content/ uploads/2011/10/

Guia_do_Eucalipto_junho_2008.pdf

DOURADO, C.S.; OLIVEIRA, S.R.M.; AVILA, A.M.H. Análise de zonas homogêneas em séries temporais de precipitação no Estado da Bahia.

Bragantia, v.72, n.2, abr/jun., 2013.

EMPRESA BRASILEIRA DE PESQUISA AGROPECUÁRIA - EMBRAPA. Centro Nacional de Pesquisa de Solos-CNPS. Sistema brasileiro de classificação de solos. Brasília: Embrapa-SPI; Rio de Janeiro: Embrapa Solos, 2006. 306p.

FERNANDES, E.T.; CAIRO, P.A.R.; MORAIS, J.L.C. Crescimento de clones de eucalipto sob deficiência hídrica. Enciclopédia Biosfera, Centro Científico Conhecer-Goiania, v.9, n.17, p.867-875, 2013. 
GALO, M.V. Resposta do eucalipto à aplicação de potássio em solo de cerrado. 1993. 40f. Dissertação (Mestrado em Solos e Nutrição de Plantas) - Univesidade Federal de Viçosa, Viçosa, MG, 1993.

GENTIL, M.S. Transpiração e eficiência do uso da água em árvores clonais de Eucalyptus aos 4 years em áreas com e sem irrigação em Eunápolis, Bahia. 2010. 71f. Dissertação (Mestrado em Recursos Florestais) - Escola Superior de Agricultura "Luiz de Queiroz", Universidade de São Paulo, Piracicaba, 2010.

GONÇALVES, M.R.; PASSOS, C.A.M. Crescimento de cinco espécies de eucalipto submetidas a déficit hídrico em dois níveis de fósforo.

Ciência Florestal, v.10, n.2, p.145-161, 2000.

GONÇALVES, J.L.M.; RAIJ, B.van; GONÇALVES, J.C. Florestais. In: RAIJ, B.van; CANTARELLA, H.; QUAGGIO, J.A.; FURLANI, A.M. C.

(Ed.) Recomendações de adubação e calagem para o Estado de São Paulo. Campinas: Instituto Agronômico e Fundação IAC, 1996. p.247-259.

JONES, D.A.; WILKINS, D.A. Variation and adaptations in plant species. London: Heinemann, 1971. 184p.

LARCHER, W. Ecofisiologia vegetal. São Carlos: Rima, 2006. 531p.

LIMA, W.P.; JARVIS, P.; RHIZOPOULOU, S. Stomatal responses of Eucalyptus species to elevated $\mathrm{CO} 2$ concentration and drought stress. Scientia Agricola, v.60, n.2, p.231-238, 2003.

MALAVOLTA, E.; VITTI, G.C.; OLIVEIRA, S.A. Avaliação do estado nutricional de plantas: princípios e aplicações. Piracicaba: Potafos, 1997. 309p.
MALAVOLTA, E. Manual de nutrição mineral de plantas. São Paulo: Agronômica Ceres, 2006. 638p.

MENESES, C.H.S.G.; LIMA L.H.G.M.; LIMA M.M.A.; VIDAL M.S. Aspectos genéticos e moleculares de plantas submetidas ao déficit hídrico. Revista de Oleaginosas e Fibrosas, v.10, n.(1/2), p.1039-72, 2006.

NOGUEIRA, R.J.M.C.; MORAES, J.A.P.V.de; BURITY, H.A.; EGÍDIO, B.N. Alterações na resistência à difusão de vapor das folhas e relações hídricas em aceroleiras submetidas a déficit de água. Revista Brasileira de Fisiologia Vegetal, v.13, n.1, p.75-87, 2001.

PROTÁSIO, T.P.; COUTO, A.M.; REIS, A.A.; TRUGILHO, P.F. Seleção de clones de Eucaliptus para a produção de carvão vegetal e bioenergia por meio de técnicas univariadas e multivariadas. Scientia Forestalis, v.41, n.97, p.15-28, 2013.

SCHIMIDT, D.V.C. Crescimento de mudas de Eucalyptus camaldulensis e Eucalyptus grandis em resposta à fertilização potássica e a calagem. 1995. 57f. Dissertação (Mestrado em Ciência Florestal) Universidade Federal de Viçosa, Viçosa, MG, 1995.

STAPE, J.L.; BINKLEY, D.; RYAN, M.G.; GOMES, A.N. Water use, water limitation and water use efficiency in a Eucalyptus plantation. Bosque, v. 25, n. 1, p. 35-41, 2004.

TATAGIBA, S.D.; MONTAGU, K.D.; CONROY, J.P. Temperature effects on wood anatomy, wood density, photosynthesis and biomass partitioning of Eucalyptus grandis seedligs. Tree

Physiology, v.27, n.2, p.251-260, 2007.

VALERI, S.V.; CORRADINI, L.; AGUIAR, I.V. Efeito de níveis de NPK e calcário dolomítico na produção volumétrica de madeira de Eucalyptus grandis Hill ex Maiden. Científica, v.19, n.1, p.63-70, 1991. 